\title{
EXOGENOUS GLUTATHIONE REDUCES THE DAMAGE INDUCED BY CADMIUM IN CUCUMBER SEEDLINGS
}

\author{
GLUTATIONA EXÓGENA REDUZ O DANO INDUZIDO POR CADMIO EM \\ PLANTULAS DE PEPINO
}

\author{
Hongyan SUN ${ }^{1 *}$; Xiaoyun WANG ${ }^{2}$; Qing HE$^{1}$; Jiewen WANG $^{1}$; Huiyan DONG ${ }^{1}$ \\ 1. College of Chemical and Biological Engineering, Taiyuan University of Science and Technology, Taiyuan 030024, P.R. China. \\ *doctor's degree, associate professor, sunhongyan-8@163.com; 2. Institute of Shanxi Soil and Water Conservation, Taiyuan 030045, \\ P.R. China
}

\begin{abstract}
Cadmium $(\mathrm{Cd})$ toxicity is a worldwide problem for crop production. The present work used hydroponic experiments to investigate the ameliorating effects and physiological mechanisms of glutathione (GSH) mitigation of $\mathrm{Cd}$ toxicity in cucumber seedlings. The results revealed that $\mathrm{Cd}$ was mainly accumulated in roots of cucumber, $100 \mu \mathrm{M}$ GSH pretreatment in $50 \mu \mathrm{M} \mathrm{Cd}$ solution significantly recovered Cd-induced growth inhibition, improved photosynthetic and chlorophyll fluorescence performance. Moreover, external GSH obviously depressed hydroxyl free radical $(\cdot \mathrm{OH})$ and malondialdehyde accumulation, increased the total antioxidant capacity in cucumber exposed to $\mathrm{Cd}$. Results indicated that pre-treatment of GSH can alleviate Cd toxicity by reducing Cd uptake and ROS accumulation, reduce the negative consequences of oxidative stress caused by $\mathrm{Cd}$ toxicity, moreover protect photosynthetic machinery from damaging, balance nutrients and antioxidants in cucumber.
\end{abstract}

L)

KEYWORDS: Cadmium. Glutathione. Reactive oxygen species. Photosynthesis. Cucumber (Cucumis sativus

\section{INTRODUCTION}

Heavy metal contamination has become one of the most important environmental problems worldwide. Cd represents a major environmental pollutant and has been classified as seventh out of 275 compounds in the priority list of hazardous materials by the Comprehensive Environmental Response, Compensation and Liability Act (ATSDR, 2008). In soil, Cd even in low concentration could enter crop plants and preferentially concentrate in their edible parts; hence, $\mathrm{Cd}$ is also a toxic trace pollutant for humans, animals and plants via food chain (BUR et al., 2010). Large number of animals exposed to high concentration of $\mathrm{Cd}$ have been found suffering from mutagenic, carcinogenic and teratogenic (DEGRAEVE, 1981). Once entering in plants, Cd can cause photosynthesis reduction, nutrient uptake decrease, and visible injury symptoms, such as chlorosis, growth inhibition, root tips browning, and finally death (KAHLE, 1993; WANG et al., 2011; LIU et al., 2015). Correspondingly, it is urgently necessary to develop approaches to prevent $\mathrm{Cd}$ accumulation in plant edible parts so as to alleviate health risks associated with exposure to highly $\mathrm{Cd}-$ containing food.

The presence of $\mathrm{Cd}$ can result in excessive generation of reactive oxygen species (ROS) which could cause cell death due to oxidative stress such as membrane lipid peroxidation, enzyme inhibition, protein oxidation and damage to nucleic acids (GILL; TUTEJA, 2010; HOSSAIN et al., 2010; GILL et al., 2011a). To repair the Cd-induced inhibitory effects of ROS, plants employ a ROSdetoxifying antioxidant defense machinery which includes non-enzymatic (reduced glutathione $(\mathrm{GSH})$, AsA, a -tocopherol and carotenoids) and enzymatic (SOD, CAT, APX, GR, MDHAR, DHAR, GPX and GST) antioxidants (GILL; TUTEJA, 2010; HOSSAIN et al., 2010; GILL et al., 2011b; LIN et al., 2012; SUN et al., 2014; LIU et al., 2015). Moreover, GSH and oxidized glutathione (GSSG) are particularly important in scavenging ROS based on the GSH-GSSG reaction and the ascorbate-glutathione cycle (NOCTOR et al., 2012). Exposure to $\mathrm{Cd}$ provoke prominent responses of antioxidative systems, but the direction of the response dependends on the plant species, plant organ, and the intensity of the $\mathrm{Cd}$ stress (SCHÜTZENDÜBEL; POLLE, 2002 ).

GSH, a naturally occurring tripeptide, is a constituent of the cellular defense mechanism of the body against various exogenous as well as endogenously produced xenobiotics, oxyradicals, salinity, acidity, and metal cations (FERGUSON; BOOTH, 1998; WU et al., 2003). Chen et al. (2010) and Wang et al. (2011) found that exogenous GSH was one of the favorable antioxidants in the defense system against $\mathrm{Cd}$ stress in barley. More 
interestingly, Chao et al. (2009) reported that rice seedlings pre-treated with $1 \mathrm{mM}$ exogenous GSH showed higher GSH level in leaves and subsequently enhanced $\mathrm{Cd}$ tolerance. In our previous study on maize seedlings, pre-treated with $100 \mu \mathrm{M}$ GSH for 24 hours significantly alleviated $50 \mu \mathrm{M}$ Cd-induced growth inhibition and dramatically diminished leaf $\mathrm{H}_{2} \mathrm{O}_{2}$ and root malondialdehyde (MDA) accumulation, significantly decreased $\mathrm{Cd}$ concentration, counteracted Cd-induced alterations of certain microelements and antioxidant enzymes (SUN et al., 2013). Besides its role in the ascorbate - glutathione cycle, glutathione can act as a first defense line against metal toxicity through complexing metals before phytochelatins (PCs) reaches to an effective level (SINGHAL et al., 1987). In addition, GSH is also an immediate substrate for synthesis of PCs (ZENK, 1996). Therefore, the question arises whether and/or how external GSH could act as a regulator in preventing $\mathrm{Cd}$ stress in cucumber seedlings.

Hence, the current work was conducted using a hydroponic system to investigate whether exogenous GSH is able to alleviate $\mathrm{Cd}$ toxicity in cucumber seedlings, we aimed to find an valid way to reduce $\mathrm{Cd}$ toxicity risks for sustainable safe production and to explore the underlying mechanism in alleviating cucumber $\mathrm{Cd}$ toxicity by external GSH application.

\section{MATERIAL AND METHODS}

\section{Plant growth and treatments}

Healthy seeds of cucumber variety Jinyan 4 were germinated in sterilized moist sand and grown for 10 days in an incubator with a $16 \mathrm{~h}$ photoperiod $\left(180 \mu \mathrm{mol} \mathrm{m} \mathrm{m}^{-2} \mathrm{~s}^{-1}\right)$ at $22^{\circ} \mathrm{C}$ to $25^{\circ} \mathrm{C}$ in Taiyuan university of science and technology, Taiyuan, China, and the relative humidity was $70 \%$. After 10 days, the uniform healthy seedlings were selected and transplanted to $5 \mathrm{~L}$ containers with a volume of 4.5-L basal nutrient solution (JANICKA-RUSSAK et al., 2012), the solution $\mathrm{pH}$ was checked for $5.6 \pm 0.1$, the solution was continuously aerated with pumps. And treatments were conducted on the $6^{\text {th }}$ day after transplanting: (1) control, basal nutrient solution; (2) GSH, $100 \mu \mathrm{M}$ GSH was added on the $5^{\text {th }}$ day after transplanting and on the next day $\left(6^{\text {th }}\right.$ day, i.e. after 24 hours pre-treated with GSH) replaced with basal nutrient solution; (3) $\mathrm{Cd}$, as 50 $\mu \mathrm{M} \mathrm{CdCl}_{2}$; and (4) $\mathrm{Cd}+\mathrm{GSH}, 24 \mathrm{~h}$ pre-treated with $100 \mu \mathrm{M} \mathrm{GSH}+50 \mu \mathrm{M} \mathrm{Cd}, \mathrm{GSH}$ was added on the $5^{\text {th }}$ day after transplanting and on the second day replaced with Cd. And seven plants per treatment in
3 replicates were made. All plants were sampled and determined after 5 days $\mathrm{Cd}$ treatment.

Chlorophyll contents, photosynthesis and chlorophyll fluorescence parameters analysis

The $2^{\text {nd }}$ fully expanded leaves (The average area was $6.2 \mathrm{~cm}^{2}$ ) of plants were used for measurement of the chlorophyll content (measured as SPAD (Soil Plant Analysis Development) values), chlorophyll fluorescence and photosynthetic parameters. SPAD value was determined using a chlorophyll meter (SPAD-502, Konica Minolta Sensing, Japan). The net photosynthetic rate $(P n)$, stomatal conductance $(G s)$, transpiration rate $(T r)$ and intercellular $\mathrm{CO}_{2}$ concentration $(\mathrm{Ci})$ were measured using a LI-6400 portable photosynthesis system (LI-COR, Lincoln, NE, USA). The chlorophyll fluorescence parameters were measured with an IMAGINGPAM (chlorophyll fluorometer) system according to Zhang et al. (2015).

\section{Plant growth and biomass, and element determination}

The height and root length of each plant were measured after 5 days Cd treatment, and then all cucumber seedlings were uprooted and separated into leaves, stems and roots. For the determination of microelement $(\mathrm{Cd}, \mathrm{Zn}, \mathrm{Cu})$ concentration, all the separated samples were dried and digested according to our previous method (SUN et al., 2014), and the detailed procedure has been described elsewhere (LIU et al., 2015).

\section{$\mathrm{OH}$, lipid peroxidation, and antioxidant capacity determination}

The fresh samples were directly used for the hydroxyl free radical $(\cdot \mathrm{OH})$ contents using a $\cdot \mathrm{OH}$ detection kit (Jiancheng Bioengineering Institutes, China) in accordance with the manufacturer's instructions. The level of lipid peroxidation was quantitated by the amount of malondialdehyde (MDA) according to $\mathrm{Wu}$ et al. (2003). The antioxidant capacity was determined using cupric reducing antioxidant capacity (CUPRAC) assay according to our previous study (LI et al., 2015), and the final results were given as $\mathrm{mg}$ gallic acid equivalents (GAE).

\section{Statistical analysis}

All data were means of three replicates and analysed with Data Processing System statistical software package using ANOVA test (TANG Q; FENG, 1997), differences among treatments were 
evaluated by the Duncan's Multiple Range Test (SSR) at significance level of $\mathrm{P} \leq 0.05$.

\section{RESULTS AND DISCUSSION}

Effect of exogenous GSH pretreatment on Cd toxicity and $\mathrm{Cd}$ concentration in cucumber seedlings

As compared with control, cucumber plants exposure to $50 \mu \mathrm{M} \mathrm{Cd}$ after 5 days induced significant decrease SPAD value, plant height, root length and biomass (Table 1), and the general symptoms of $\mathrm{Cd}$ exposure to plants was leaf chlorosis (SUN et al., 2014), which was consistent with the present results. Pretreatment with $100 \mu \mathrm{M}$ GSH for $24 \mathrm{~h}$ before $50 \mu \mathrm{M}$ Cd stress $(\mathrm{Cd}+\mathrm{GSH})$ significantly alleviated Cd-induced growth inhibition, i.e. after 5 days $\mathrm{Cd}+\mathrm{GSH}$ treatment, SPAD value, plant height and root length increased significantly by $12.8 \%, 11.5 \%$ and $21.7 \%$ compared with $\mathrm{Cd}$ alone treatment.

Table 1. Effect of Cd and GSH in nutrient media on SPAD value, plant height, root length and biomass of cucumber seedlings exposed to Cd for 5 days.

\begin{tabular}{lllllll}
\hline Treatment & SPAD value & $\begin{array}{l}\text { Plant height } \\
(\mathrm{cm})\end{array}$ & $\begin{array}{l}\text { Root length } \\
(\mathrm{cm})\end{array}$ & $\begin{array}{l}\text { Leaf DW } \\
\left(\mathrm{mg} \mathrm{plant}^{-1}\right)\end{array}$ & $\begin{array}{l}\text { Stem DW } \\
\left(\mathrm{mg} \mathrm{plant}^{-1}\right)\end{array}$ & $\begin{array}{l}\text { Root DW } \\
\left(\mathrm{mg} \mathrm{plant}^{-1}\right)\end{array}$ \\
\hline Control & $28.0^{\mathrm{a}}$ & $22.5^{\mathrm{a}}$ & $18.7^{\mathrm{a}}$ & $75.1^{\mathrm{a}}$ & $45.4^{\mathrm{a}}$ & $11.5^{\mathrm{a}}$ \\
GSH & $27.4^{\mathrm{a}}$ & $21.3^{\mathrm{a}}$ & $17.2^{\mathrm{a}}$ & $72.0^{\mathrm{a}}$ & $43.7^{\mathrm{a}}$ & $10.4^{\mathrm{a}}$ \\
Cd & $23.4^{\mathrm{b}}$ & $19.2^{\mathrm{b}}$ & $12.0^{\mathrm{c}}$ & $56.3^{\mathrm{c}}$ & $32.2^{\mathrm{c}}$ & $7.8^{\mathrm{b}}$ \\
Cd+GSH & $26.4^{\mathrm{a}}$ & $21.4^{\mathrm{a}}$ & $14.6^{\mathrm{b}}$ & $65.1^{\mathrm{b}}$ & $38.2^{\mathrm{b}}$ & $9.5^{\mathrm{a}}$ \\
\hline
\end{tabular}

* Means followed by same letter in columns do not differ statistically among themselves by Duncan test (p>0.05). DW, dry weight.

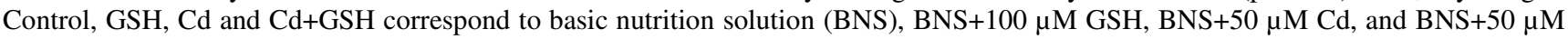
$\mathrm{Cd}+100 \mu \mathrm{M}$ GSH, respectively.

It has been shown that $\mathrm{Cd}$ was more accumulated in roots than in the aerial parts (leaves and stems) after $\mathrm{Cd}$ treatment. Furthermore, GSH pretreatment $(\mathrm{Cd}+\mathrm{GSH})$ suppressed $\mathrm{Cd}$ uptake, and leaf, stem and root $\mathrm{Cd}$ concentrations reduced by $27.5 \%, 29.8 \%$ and $33.1 \%$, prespectively, when compared with those in $\mathrm{Cd}$ alone treatment (Table
2). No significant differences were observed between GSH pretreatment and control which were below the detection limit. The results suggested a practical potential for exogenous GSH pretreatment as an intervention strategy in mitigating $\mathrm{Cd}$ stress and reducing $\mathrm{Cd}$ uptake and translocation in cucumber plants.

Table 2. Effect of Cd and GSH pretreatment on element concentrations in leaves, stems and roots of cucumber seedlings.

\begin{tabular}{llllllllll}
\hline \multirow{2}{*}{ Treatment } & Leaf & \multicolumn{3}{c}{ Stem } & \multicolumn{3}{c}{ Root } \\
\cline { 2 - 10 } & $\mathrm{Cd}$ & $\mathrm{Zn}$ & $\mathrm{Cu}$ & $\mathrm{Cd}$ & $\mathrm{Zn}$ & $\mathrm{Cu}$ & $\mathrm{Cd}$ & $\mathrm{Zn}$ & $\mathrm{Cu}$ \\
\hline Control & - & $134.8^{\mathrm{a}}$ & $30.9^{\mathrm{b}}$ & - & $248.1^{\mathrm{a}}$ & $59.4^{\mathrm{a}}$ & - & $550.4^{\mathrm{a}}$ & $63.5^{\mathrm{a}}$ \\
GSH & - & $130.2^{\mathrm{a}}$ & $29.2^{\mathrm{b}}$ & - & $242.2^{\mathrm{a}}$ & $55.4^{\mathrm{a}}$ & - & $542.4^{\mathrm{a}}$ & $68.9^{\mathrm{a}}$ \\
$\mathrm{Cd}$ & $43.6^{\mathrm{a}}$ & $87.5^{\mathrm{b}}$ & $20.2^{\mathrm{c}}$ & $183.3^{\mathrm{a}}$ & $159.7^{\mathrm{b}}$ & $33.7^{\mathrm{b}}$ & $904.8^{\mathrm{a}}$ & $470.9^{\mathrm{b}}$ & $49.0^{\mathrm{b}}$ \\
$\mathrm{Cd}+\mathrm{GSH}$ & $31.6^{\mathrm{b}}$ & $92.1^{\mathrm{b}}$ & $44.3^{\mathrm{a}}$ & $128.7^{\mathrm{b}}$ & $163.5^{\mathrm{b}}$ & $65.8^{\mathrm{a}}$ & $604.9^{\mathrm{b}}$ & $502.8^{\mathrm{ab}}$ & $66.0^{\mathrm{a}}$ \\
\hline
\end{tabular}

Values are in $\mathrm{mg} \mathrm{kg}^{-1}$ DW. - , not detected.

In plants, Cd stress can disturb the metabolism of some micronutrients. The interactions of $\mathrm{Cd}$ and metal nutrients have been reported in some upland crops, such as wheat (ZHANG et al., 2002), barley (WANG et al., 2011; MUHAMMAD et al., 2012; SUN et al., 2014), and tomato (SMITH; BRENNAN, 1983). However, the interactions between $\mathrm{Cd}$ and other nutrients were complicated and quite different with species. Our previous study found that there was a significantly negative correlation between $\mathrm{Zn}, \mathrm{Cu}$, or $\mathrm{Mn}$ concentration and $\mathrm{Cd}$ concentration in barley plants (SUN et al., 2014). The same effects were observed in the present experiment. Cucumber plants exposed to $50 \mu \mathrm{M} \mathrm{Cd}$ significantly reduced $\mathrm{Zn}$ and $\mathrm{Cu}$ concentrations in all tissues, external GSH noticeably recovered leaf, stem and root $\mathrm{Cu}$, and leaf $\mathrm{Cu}$ concentration was higher than control level, e.g. leaf $\mathrm{Cu}$ concentration in $\mathrm{Cd}+\mathrm{GSH}$ treatment being 2.19 fold higher than $\mathrm{Cd}$ alone treatment (Table 2), indicating that GSH can mitigate $\mathrm{Cd}$ toxicity in cucumber through balancing the elements metabolism. 


\section{Photosynthetic and chlorophyll fluorescence parameters in leaves of cucumber seedlings}

Earlier investigations have demonstrated that there was a notable reduction in $P n$ by $\mathrm{Cd}$ treatment in many plant species (CAI et al., 2011; BASZYNSKI et al., 1980). In the present research, the results were also consistent with these observations, cucumber plants exposed to $50 \mu \mathrm{M} \mathrm{Cd}$ showed a sharp decrease in $P n$, being $28.5 \%$ lower compared with the control condition (Table 3), which accompanied with marked reduction in $T r$ and $G s$. Furthermore, the $C i$ increased significantly after $\mathrm{Cd}$ treatment, while $\mathrm{Cd}+\mathrm{GSH}$ suppressed $\mathrm{Cd}$ induced increase, therefore the inhibition of photosynthetic processes by $\mathrm{Cd}$ in cucumber was due to nonstomatal restriction. In addition, GSH pretreatment $(\mathrm{Cd}+\mathrm{GSH})$ improved cucumber photosynthetic ability inhibited by $\mathrm{Cd}$ stress, with the $P n$ increased significantly by $21.0 \%$, which might likely link to protective mechanisms that maintain the integrity of the photosynthetic machinery.

Table 3. Effect of external GSH pretreatment on photosynthesis and chlorophyll fluorescence parameters of cucumber seedlings exposed to $\mathrm{Cd}$ for 5 days.

\begin{tabular}{llllllll}
\hline \multirow{2}{*}{ Treatment } & $\begin{array}{l}\mathrm{Pn}\left(\mu \mathrm{MCO}_{2}\right. \\
\left.\mathrm{m}^{-2} \mathrm{~s}^{-1}\right)\end{array}$ & $\begin{array}{l}\operatorname{Tr}\left(\mathrm{mMH}_{2} \mathrm{O}\right. \\
\left.\mathrm{m}^{-2} \mathrm{~s}^{-1}\right)\end{array}$ & $\begin{array}{l}\mathrm{Gs}\left(\mathrm{mM} \mathrm{H} \mathrm{H}_{2} \mathrm{O} \mathrm{m}{ }^{-2} \mathrm{Ci}(\mu \mathrm{M}\right. \\
\left.\mathrm{s}^{-1}\right)\end{array}$ & $\mathrm{CO}_{2} \mathrm{~F}_{0}$ & Fv/Fm & $\mathrm{Y}(\mathrm{NO})$ \\
\hline Control & $16.2^{\mathrm{a}}$ & $2.4^{\mathrm{a}}$ & $110.3^{\mathrm{a}}$ & $329^{\mathrm{c}}$ & $0.055^{\mathrm{b}}$ & $0.849^{\mathrm{a}}$ & $0.155^{\mathrm{b}}$ \\
$\mathrm{GSH}$ & $16.1^{\mathrm{a}}$ & $2.6^{\mathrm{a}}$ & $109.4^{\mathrm{a}}$ & $326^{\mathrm{c}}$ & $0.050^{\mathrm{b}}$ & $0.860^{\mathrm{a}}$ & $0.140^{\mathrm{b}}$ \\
$\mathrm{Cd}$ & $11.6^{\mathrm{c}}$ & $1.9^{\mathrm{b}}$ & $75.4^{\mathrm{bc}}$ & $415^{\mathrm{a}}$ & $0.071^{\mathrm{a}}$ & $0.820^{\mathrm{b}}$ & $0.173^{\mathrm{a}}$ \\
$\mathrm{Cd}+\mathrm{GSH}$ & $14.0^{\mathrm{b}}$ & $2.1^{\mathrm{ab}}$ & $85.4^{\mathrm{b}}$ & $377^{\mathrm{b}}$ & $0.053^{\mathrm{b}}$ & $0.858^{\mathrm{ab}}$ & $0.142^{\mathrm{b}}$ \\
\hline
\end{tabular}

$P n$ net photosynthetic rate, $\operatorname{Tr}$ transpiration rate, $G s$ stomatal conductance, $C i$ intercellular $\mathrm{CO}_{2}$ concentration.

The initial fluorescence $\left(F_{0}\right)$ and the maximum efficiency of photosystem II photochemistry $(F v / F m)$ were widely used as reliable diagnostic indicators of photoinhibition (Krause, 1988). $F v / F m$ was decreased exposing to $50 \mu \mathrm{M} \mathrm{Cd}$ treatment, however, $F_{0}$ and quantum yield of nonregulated energy dissipation $Y(N O)$ increased significantly (Table 3 ), similar results were observed in barley, rice and tobacco of $F v / F m$ value being decreased significantly under Cd stress (WANG et al., 2011; CAI et al., 2011; LIU et al., 2015). The $F_{0}$ was also the fluorescent when the reaction center of photosystem II (PSII) was all open, and the increase in $F_{0}$ under $\mathrm{Cd}$ stress indicated the injury of PSII. Considerable change of $Y(N O)$ under $\mathrm{Cd}$ stress indicated there was severe irreversible photodamage to PSII (KRAMER et al., 2004). On the other hand, the decrease of $F v / F m$ under $\mathrm{Cd}$ stress also indicated that the photochemistry of PSII and its ability to reduce the primary acceptor $\mathrm{Q}_{\mathrm{A}}$ were also affected by $\mathrm{Cd}$, and they were sensitive to environmental changes, which affected efficiency to capture excitation energy by open PSII reaction center (BABANI; LICHTENTHALER, 1996). On the contrary, GSH pretreatment $(\mathrm{Cd}+\mathrm{GSH})$ improved the $F v / F m$ ratio back to control level, and obviously suppressed $\mathrm{Cd}$ induced increase in the $F_{0}$ and $Y(N O)$ by $25.4 \%$ and $17.9 \%$, respectively, indicating GSH regulated photosynthesis improvement partly owing to the chlorophyll synthesis increase and the protection of photosystem II reaction center, which were significant for improving $\mathrm{Cd}$ tolerance in cucumber.
GSH eliminated Cd-induced over-accumulation of MDA, $\cdot \mathrm{OH}$, and elevated Cd-depressed antioxidant capacity in cucumber seedlings

Oxidative stress was a central part of abiotic and biotic stresses, ROS such as $\mathrm{O}_{2}{ }^{-}, \mathrm{H}_{2} \mathrm{O}_{2}$ and $\cdot \mathrm{OH}$ were often produced in large quantities by plants during various stress responses (CHEN et al., 2010; VIEHWEGER, 2014), in order to protect against oxidative stress, plants have evolved enzymatic and non-enzymatic ROS scavenging systems.

Our results showed that Cd-induced accumulation of $\cdot \mathrm{OH}$ and MDA in leaves, stems and roots of cucumber seedlings, which were markedly reduced by GSH pretreatment (Fig. 1). GSH was one of the non-enzymatic components acting as an antioxidant, and it was involved directly in the reduction of most ROS (NOCTOR and FOYER, 1998); additionally, GSH played a key role in the antioxidative defense system by regenerating other potential water-soluble antioxidants like AsA via the AsA-GSH cycle (FOYER and HALLIWELL, 1976). In present study, GSH pretreatment significantly reduced MDA content although its value still lower than that in control, for example, in leaves, stems and roots, it decreased by $31.8 \%$, $28.2 \%$ and $13.6 \%$ under $\mathrm{Cd}+\mathrm{GSH}$, respectively, compared with the Cd-alone treatment (Figure 1A, $\mathrm{B}$ and $\mathrm{C})$. The variation of $\cdot \mathrm{OH}$ content showed a similar trend to that of MDA (Figure 1D, E and F). Antioxidant capacity expressed as CUPRAC value was significantly reduced in all tissues under $\mathrm{Cd}$ treatment compared with control, and especially in 
roots, reduced by $72.2 \%$. Importantly, CUPRAC value increased under $\mathrm{Cd}+\mathrm{GSH}$ condition although the value was lower than that observed in the control (Figure 1G, H and I)
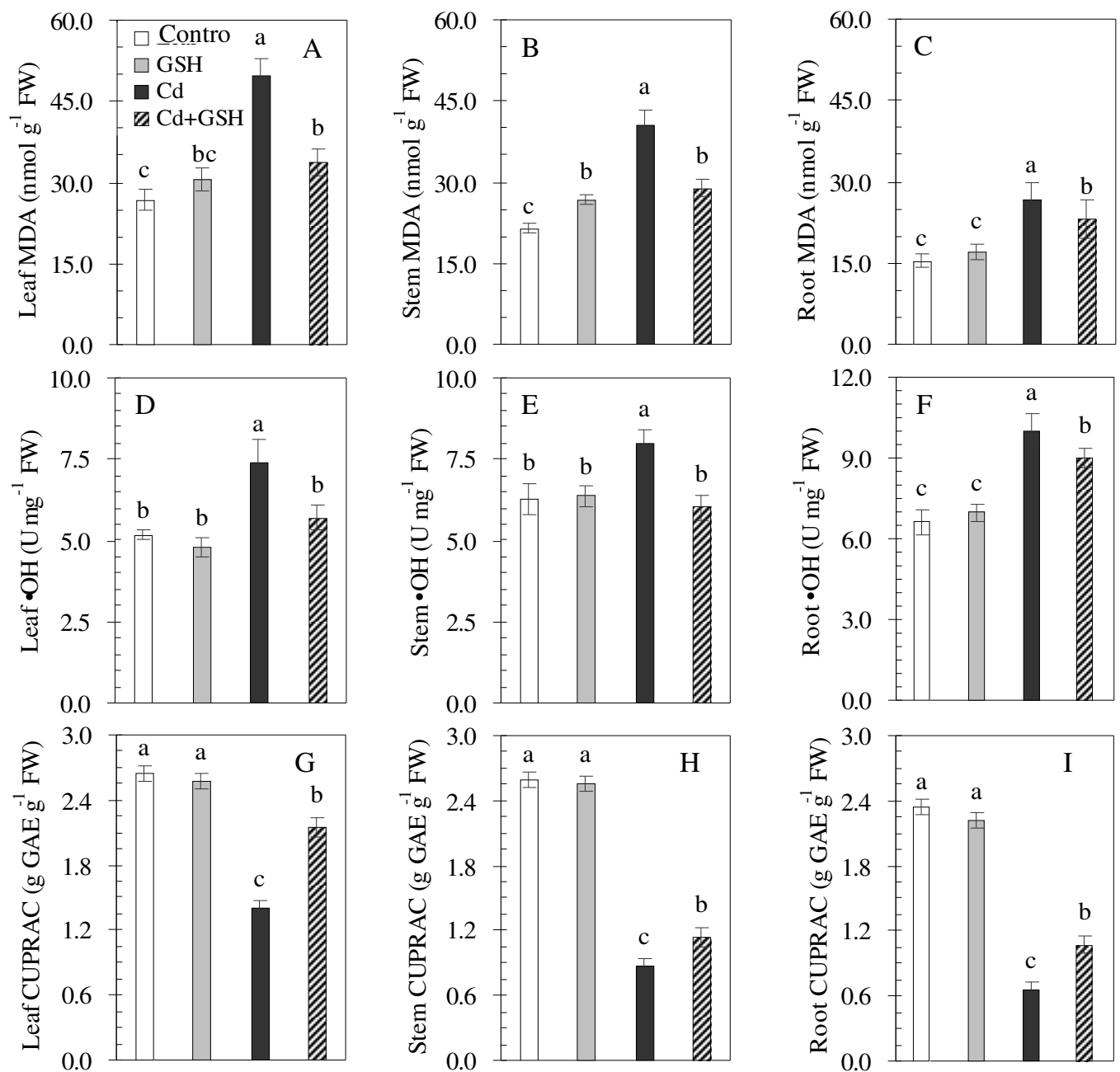

Figure 1. Effect of external GSH pretreatment on MDA accumulation, $\cdot \mathrm{OH}$ content and cupric reducing antioxidant capacity (CUPRAC) in leaves, stems and roots of cucumber seedlings exposed to Cd for 5 days. FW and GAE represent fresh weight and gallic acid equivalent, respectively.

\section{CONCLUSIONS}

The protective role of GSH in alleviation of Cd-induced growth inhibition in cucumber was complicated.

The mechanism involved in the prevention of Cd stress is mainly linked to the decreased $\mathrm{Cd}$ in leaves, stems and roots and dramatically depressed . $\mathrm{OH}$ and MDA accumulation, and elevated $\mathrm{Cd}$ depressed antioxidant capacity in cucumber seedlings compared with $\mathrm{Cd}$ treatment. This result also suggests that GSH has antioxidant properties or that GSH activates protective mechanisms that can alleviate oxidative stress in non-enzymatic ways. On the other hind, GSH ameliorated Cd-induced reduction in chlorophyll content, improved photosynthetic and chlorophyll fluorescence performance. Furthermore, the alleviating effect of
GSH was associated with balanced nutrient elements in cucumber plants. These results may facilitate a better understanding of the mechanisms involved in $\mathrm{GSH}$-mediated tolerance to $\mathrm{Cd}$ stress in cucumber.

\section{ACKNOWLEDGMENTS}

This work was supported by the National Natural Science Foundation of China (31401319), the Program for the Top Young Academic Leaders of Higher Learning Institutions of Shanxi of China (20151006), Shanxi Province Science Foundation for Youths (2015021146), and the Scientific Research Foundation for Doctoral Scholars of Taiyuan University of Science and Technology of China (HY201301). 
RESUMO: A toxicidade do Cádmio $(\mathrm{Cd})$ é um problema mundial para a produção de plantas olerícolas. O presente trabalho com o uso experimentos hidropônicos objetivou investigar a atenuação dos efeitos do cádmio por meio de mecanismos envolvendo a glutationa (GSH) e redução da toxicidade em plântulas de pepino submetidas ao Cd. OS resultados revelaram que o $\mathrm{Cd}$ acumulou principalmente nas raízes do pepino, Na dose de $100 \mu \mathrm{M}$ GSH-50 esta reduziu a concentração em $\mu \mathrm{M}$ Cd na solução ea mesma melhora a ou reduz a inibição do crescimento ,bem como melhora o desempenho e a fluorescência clorofílica. Além disso, obviamente, radical Livre hidroxila GSH externa $\cdot \mathrm{OH})$ aumenta a acumulação do malondialdeído e aumento da capacidade antioxidante total no pepino expostos ao Cd. OS resultados indicaram que o pré -tratamento de GSH pode reduzir a toxicidade, reduzindo a captação Cd e acumulação ROS , reduzir os efeitos negativos do stress oxidativo reduzindo a sua toxicidade, além de proteger o equilíbrio da disponibilidade de nutrientes e antioxidantes. sativus $\mathrm{L}$ )

PALAVRAS-CHAVE: Cádmio. Glutationa. Espécies reativas de oxigênio. Fotossíntese. Pepino (Cucumis

\section{REFERENCES}

ASTOLFI, S.; ZUCHI, S.; CHIANI, A.; PASSERA, C. In vivo and in vitro effects of cadmium on $\mathrm{H}^{+}$-ATPase activity of plasma membrane vesicles from oat (Avena sativa L.) roots. J. Plant Physiol. v. 160, p. 387-393, 2003. http://dx.doi.org/10.1078/0176-1617-00832

ATSDR. Draft toxicological profile for cadmium. US Department of Health and Human Services, Atlanta, 2008.

BABANI, F.; LICHTENTHALER, H. K. Light-induced and age-dependent development of chloroplasts in etiolated barley leaves as visualized by determination of photosynthetic pigments, $\mathrm{CO}_{2}$ assimilation rates and different kinds of chlorophyll fluorescence ratios. J. Plant Physiol. v. 148, p. 555-566, 1996.

http://dx.doi.org/10.1016/S0176-1617(96)80075-7

BANERJEE, S; FLORES-ROZAS, H. Cadmium inhibits mismatch repair by blocking the ATPase activity of the MSH2-MSH6 complex. Nucleic Acids Res. v. 33, p. 1410-1419, 2005.

http://dx.doi.org/10.1093/nar/gki330 http://dx.doi.org/10.1093/nar/gki291

BASZYNSKI, T.; WAJDA, L.; KROL, M.; WOLINSKA, D.; KRUPA, Z.; TUKENDORF, A. Photosynthetic activities of cadmium-treated plants. Physiol. Plantarum, v. 48, p. 365-370, 1980.

http://dx.doi.org/10.1111/j.1399-3054.1980.tb03269.x

CAI, Y.; CAO, F. B.; CHENG, W. D.; ZHANG, G. P.; WU, F. B. Modulation of exogenous glutathione in phytochelatins and photosynthetic performance against Cd Stress in the two rice genotypes differing in $\mathrm{Cd}$ tolerance. Biol. Trace Elem. Res. v. 143, p. 1159-1173, 2011. http://dx.doi.org/10.1007/s12011-010-8929-1

CHAO, Y. Y.; HSU, T. Y.; KAO, H. C. Involvement of glutathione in heat shock- and hydrogen peroxideinduced cadmium tolerance of rice (Oryza sativa L.) seedlings. Plant Soil, v. 318, p. 37-45, 2009. http://dx.doi.org/10.1007/s11104-008-9815-x

CHEN, F.; WANG, F.; WU, F. B.; MAO, W. H.; ZHANG, G. P.; ZHOU, M. X. Modulation of exogenous glutathione in antioxidant defense system against $\mathrm{Cd}$ stress in the two barley genotypes differing in $\mathrm{Cd}$ tolerance. Plant Physiol. Biochem. v. 48, p. 663-72, 2010. http://dx.doi.org/10.1016/j.plaphy.2010.05.001

DEGRAEVE, N. Carcinogenic, teratogenic and mutagenic effects of cadmium. Mutat. Res. v. 86, p. 115-35, 1981. http://dx.doi.org/10.1016/0165-1110(81)90035-X

FERGUSON, G. P.; BOOTH, I. R. Importance of glutathione for growth and survival of Escherichia coli cells, detoxification of methylglyoxal and maintenance of intracellular K ${ }^{+}$. J. Bacteriol. v. 180, p. 4314-4318, 1998. 
FOYER, C. H.; HALLIWELL, B. The presence of glutathione and glutathione reductase in chloroplasts: a proposed role in ascorbic acid metabolism. Planta, Berlim, v. 133, p. 21-25, 1976.

http://dx.doi.org/10.1007/bf00386001

GILL, S. S.; KHAN, N. A.; ANJUM, N. A.; TUTEJA, N. Differential cadmium stress tolerance in five Indian mustard (Brassica juncea L.) cultivars: an evaluation of the role of antioxidant machinery. Plant Signal.

Behav. v. 6, p. 293-300, 2011a. http://dx.doi.org/10.4161/psb.6.2.15049

GILL, S. S.; KHAN, N. A.; ANJUM, N. A.; TUTEJA, N. Amelioration of cadmium stress in crop plants by nutrient management: morphological, physiological and biochemical aspects. Plant Stress, v. 5, p. 1-23, $2011 b$.

GILL, S. S.; TUTEJA, N. Reactive oxygen species and antioxidant machinery in abiotic stress tolerance in crop plants. Plant Physiol. Biochem. v. 48, p. 909-930, 2010. http://dx.doi.org/10.1016/j.plaphy.2010.08.016

HOSSAIN, M. A.; HASANUZZAMAN, M.; FUJITA, M. Up-regulation of antioxidant and glyoxalase systems by exogenous glycinebetaine and proline in mung bean confer tolerance to cadmium stress. Physiol. Mol. Biol. Plants, v. 16, p. 259-272, 2010. http://dx.doi.org/10.1007/s12298-010-0028-4

JANICKA-RUSSAK, M.; KABAŁA, K.; BURZYŃSKI, M. Different effect of cadmium and copper on $\mathrm{H}^{+}-$ ATPase activity in plasma membrane vesicles from Cucumis sativus roots. J. Exp. Bot. v. 63, n. 11, p. $4133-$ 4142, 2012. http://dx.doi.org/10.1093/jxb/ers097

KABATA-PENDIAS, A.; PENDIAS, H. Trace elements in soils and plants. 3rd edition: CRC press Inc. Boca Raton, Florida, 2001.

KAHLE, H. Response of roots of trees to heavy metals. Environ. Exp. Bot. v. 33, p. 99-119, 1993. http://dx.doi.org/10.1016/0098-8472(93)90059-O

KRAMER, D. M.; JOHNSON, G.; KIIRATS, O.; EDWARDS, G. E. New fluorescence parameters for the determination of QA redox state and excitation energy fluxes. Photosynth Res. v. 79, p. 209-218, 2004. http://dx.doi.org/10.1023/B:PRES.0000015391.99477.0d

KRAUSE, G. H. Photoinhibition of photosynthesis. An evaluation of damaging and protective mechanisms. Physiol. Plantarum, v. 74, p. 566-574, 1988. http://dx.doi.org/10.1111/j.1399-3054.1988.tb02020.x

LI, W. B.; SUN, H. Y.; ZHOU, J. W.; ZHANG, Y. B.; LIU, L. J.; GAO, Y. Antibacterial activities, antioxidant contents and antioxidant properties of three traditional Chinese medicinal extracts. Bangladesh J. Pharmacol. v. 10, p. 131-37, 2015. http://dx.doi.org/10.3329/bjp.v10i1.21324

LIN, L.; ZHOU, W. H.; DAI, H. X.; CAO, F. B.; ZHANG, G. P.; WU, F. B. Selenium reduces cadmium uptake and mitigates cadmium toxicity in rice. J. Hazard. Mater. v. 235, p. 343-351, 2012.

http://dx.doi.org/10.1016/j.jhazmat.2012.08.012

LIU, W. X.; SHANG, S. H.; FENG, X.; ZHANG, G. P.; WU, F. B. Modulation of exogenous selenium in cadmium-induced changes in antioxidative metabolism, cadmium uptake, and photosynthetic performance in the 2 tobacco genotypes differing in cadmium tolerance. Environ. Toxicol. Chem. v. 34, p. 92-99, 2015. http://dx.doi.org/10.1002/etc. 2760

MUHAMMAD, D.; CAO, F. B.; JAHANGIR, M. M.; ZHANG, G. P.; WU, F. B. Alleviation of aluminum toxicity by hydrogen sulfide is related to elevated ATPase, and suppressed aluminum uptake and oxidative stress in barley. J. Hazard. Mater. v. 209-210, p. 121-128, 2012. 
NOCTOR, G.; FOYER, C. H. Ascorbate and glutathione: keeping active oxygen under control. Annu. Rev. Plant Physiol. Plant Mol. Biol. v. 49, p. 249-279, 1998. http://dx.doi.org/10.1146/annurev.arplant.49.1.249

NOCTOR, G.; MHAMDI, A.; CHAOUCH, S.; HAN, Y.; NEUKERMANS, J.; MARQUEZ-GARCIA, B.; QUEVAL, G.; FOYER, C. Glutathione in plants: an integrated overview. Plant Cell Environ. v. 35, p. 45484, 2012. http://dx.doi.org/10.1111/j.1365-3040.2011.02400.x

SCHÜTZENDÜBEL, A.; POLLE, A. Plant responses to abiotic stresses: heavy metal-induced oxidative stress and protection by mycorrhization. J. Exp. Bot. v. 53, p. 1351-1365, 2002.

http://dx.doi.org/10.1093/jexbot/53.372.1351

SHEN, H.; HE, L. F.; SASAKI, T.; YAMAMOTO, Y.; ZHENG, S. J.; LIGABA, A.; YAN, X. L.; AHN, S. J.; YAMAGUCHI, M.; HIDEO, S.; MATSUMOTO, H. Citrate secretion coupled with the modulation of soybean root tip under aluminum stress: up-regulation of transcription, translation, and threonine-oriented phosphorylation of plasma membrane $\mathrm{H}^{+}$-ATPase. Plant Physiol. v. 138, p. 287-296, 2005. http://dx.doi.org/10.1104/pp.104.058065

SINGHAL, R. K.; ANDERSON, M. E.; MEISTER, A. Glutathione, a first line of defense against cadmium toxicity. FASEB J. v. 1, p. 220-223, 1987.

SMITH, G. C.; BRENNAN, E. G. Cadmium-zinc interactionship in tomato plants. Phytopathology, v. 73, p. 879-882, 1983. http://dx.doi.org/10.1094/Phyto-73-879

SUN, H. Y.; WANG, X. Y.; DAI, H. X.; ZHANG, G. P.; WU, F. B. Effect of exogenous glutathione and selenium on cadmium-induced changes in cadmium and mineral concentrations and antioxidative metabolism in maize seedlings. Asian J. Chem. v. 25, p. 2970, 2013. http://dx.doi.org/10.1007/s10725-014-9906-z

SUN, H. Y.; ZHANG, X. H.; HE, X. Y.; AHMED, I. M.; CAO, F. B.; ZHANG, G. P.; WU, F. B. N-acetylcysteine alleviates $\mathrm{Cd}$ toxicity and reduces $\mathrm{Cd}$ uptake in the two barley genotypes differing in Cd tolerance. Plant Growth Regul. v. 74, p. 93-105, 2014.

TANG Q, FENG MG. Practical statistics and its DPS statistical software package. China Agriculture, Beijing, 1997.

WANG, F.; CHEN, F.; CAI, Y.; ZHANG, G. P.; WU, F. B. Modulation of exogenous glutathione in ultrastructure and photosynthetic performance against $\mathrm{Cd}$ stress in the two barley genotypes differing in $\mathrm{Cd}$ tolerance. Biol. Trace Elem. Res. v. 144, p. 1275-1288, 2011. http://dx.doi.org/10.1007/s12011-011-9121-y

WU, F. B.; ZHANG, G. P.; DOMINY, P. Four barley genotypes respond differently to cadmium, lipid peroxidation and activities of antioxidant capacity. Environ. Exp. Bot. v. 50, p. 67-78, 2003.

http://dx.doi.org/10.1016/S0098-8472(02)00113-2

YAN, F.; ZHU, Y. Y.; MÜLLER, C.; ZÖRB, C.; SCHUBERT, S. Adaptation of $\mathrm{H}^{+}$-pumping and plasma membrane $\mathrm{H}^{+}$-ATPase activity in proteoid roots of white lupin under phosphate deficiency. Plant Physiol. v. 129, p. 50-63, 2002. http://dx.doi.org/10.1104/pp.010869

ZENK, M. H. Heavy metal detoxification in higher plants—a review. Gene, v. 179, p. 21-30, 1996. http://dx.doi.org/10.1016/S0378-1119(96)00422-2

ZHANG, G. P.; FUKAMI, M.; SEKIMOTO, H. Influence of cadmium on mineral concentrations and yield components in wheat genotypes differing in Cd tolerance at seedling stage. Field Crops Res. v. 77, p. 93-99, 2002. http://dx.doi.org/10.1016/S0378-4290(02)00061-8 
ZHANG, M.; JIN, Z. Q.; ZHAO, J.; ZHANG, G. P.; WU, F. B. Physiological and biochemical responses to drought stress in cultivated and Tibetan wild barley. Plant Growth Regul. v. 75, p. 567-574, 2015. http://dx.doi.org/10.1007/s10725-014-0022-x 